\title{
On-farm Phenotypic Characterization of Indigenous Chicken and their Production System in Bench Maji Zone, South Western Ethiopia
}

\author{
Getachew Bekele $^{1^{*}}$, Kefelegn Kebede $^{2}$ and Negassi Ameha ${ }^{2}$ \\ ${ }^{1}$ Departement of Animal Science, College of Agriculture and Natural Resources, Gambella University, \\ Gambella, Ethiopia \\ ${ }^{2}$ School of Animal and Range Sciences, Haramaya University, Dire Dawa, Ethiopia
}

\begin{tabular}{|c|c|}
\hline Abstract & Article Information \\
\hline $\begin{array}{l}\text { Knowledge and understanding of the chicken production system, unique characteristics, } \\
\text { opportunities and constraints are important in the design and implementation of indigenous } \\
\text { chicken based development programs. The indigenous chickens have been neglected in the } \\
\text { conservation and development programs. Therefore, this study was conducted from } \\
\text { September } 2013 \text { to May } 2014 \text { in nine selected peasant associations of North bench, Sheko } \\
\text { and South bench Woreda's located in Bench Maji Zone of South western of Ethiopia with the } \\
\text { objective to describe indigenous chicken husbandry practices and characterize phenotypic ally } \\
\text { the indigenous chicken types. The study involved both questionnaire survey and a } \\
\text { participatory group discussion. A total of } 180 \text { indigenous chicken owning farmers and } 660 \\
\text { chickens (180 male and } 480 \text { females) aged more than } 6 \text { month were considered under field } \\
\text { condition. The hatchability and survival rate of chicks were } 77.47 \% \text { and } 66.46 \% \text {. Significant } \\
\text { (p<0.05) differences were found among the districts in traits. The red, Gebsima and white } \\
\text { plumage color were dominated in the study area. The local chickens possessed yellow } \\
\text { shanks, white skin, single combs and white and red earlobe. The mean body weight of } \\
\text { indigenous male and female chickens was } 1.42 \pm 0.02 \text { kg and } 1.18 \pm 0.01 \text { kg, respectively. The } \\
\text { effective population size ranged from } 4.79 \text { (North bench) to } 3.81 \text { (Sheko) and } 3.79 \text { (South } \\
\text { bench) which resulted in } 0.104,0.131,0.132 \text {, rate of increase in inbreeding in the study district } \\
\text { respectively. Generally, morphological and phenotypically variations were observed among the } \\
\text { indigenous chicken populations, which suggest that there is an opportunity for genetic } \\
\text { improvement through selection. } \\
\text { Copyright@2015 STAR Journal, Wollega University. All Rights Reserved. }\end{array}$ & $\begin{array}{l}\text { Article History: } \\
\text { Received : 05-01-2015 } \\
\text { Revised : 17-03-2015 } \\
\text { Accepted : 19-13-2015 } \\
\text { Keywords: } \\
\text { Scavenging } \\
\text { Households } \\
\text { Productivity } \\
\text { Plumage color } \\
\text { Chicken management } \\
\text { *Corresponding Author: } \\
\text { Getachew Bekele } \\
\text { E-mail: } \\
\text { gechobek@gmail.com }\end{array}$ \\
\hline
\end{tabular}

\section{INTRODUCTION}

Poultry farming is widely practiced in Africa and almost every farmstead keeps some poultry mainly for consumption and cash sales. Religions and cultural considerations are also amongst the reasons for keeping chickens by resource poor farmers in Africa (Dwinger et al., 2003). Similarly, households in Ethiopia keep birds for household consumption, sale and reproduction purposes including other social and cultural roles (Tadele and Peter, 2003). Ethiopia, with its wide variations in agro-climatic conditions, possesses one of the largest and the most diverse plant and animal genetic resources in the world. Indigenous chickens in Ethiopia are found in huge numbers distributed across different agro ecological zones under a traditional family-based scavenging management system (Alemu and Tadele, 1997). This indicates that, they are highly important farm animals kept as a source of animal protein and income to most of the rural populations. Knowledge and understanding of the chicken production system, unique characteristics, opportunities and constraints are important in the design and implementation of indigenous chicken based development programs, (Gueye, 1998).
Report of CSA (2012/13) revealed that 96.9, 0.54 and $2.56 \%$ indigenous, hybrid and exotic chicken breeds respectively. A substantial phenotypic diversity for various traits in the indigenous chicken genetic resources of Ethiopia is expected because of diverse agro climates, ethnic groups, socioeconomic, religious and cultural variations. In addition, the country has served as one of the gateways for domestic animals migration from Asia to Africa and this has led to a further impact on the diversity of Ethiopian chickens (Halima, 2007). Improvement and conservation of indigenous chicken resource demands characterization of the available genotypes. However, only limited efforts were made to characterize the existing chicken ecotype of the country on a comprehensive standard. In general indigenous chickens are non descriptive, with a variety of morphological appearances (Halima, 2007). Tadele (2003) studied on five indigenous chicken ecotypes up to 18 weeks of age, which was selected from different parts of the country. Therefore, this study was aimed to generate the relevant information regarding the indigenous chicken genetic resources of Bench Maji Zone. Hence, the objective of this study was 
to describe indigenous chicken husbandry practices, identify and characterize phenotypically the indigenous chicken type's population in Bench Maji Zone.

\section{MATERIALS AND METHODS}

Description of the Study Area: This study was conducted in Bench Maji Zone (BMZ) which is located in the south western part of Ethiopia. BMZ is found at distance about $561 \mathrm{~km}$ from Addis Ababa and $842 \mathrm{~km}$ from the regional capital Hawassa. It is bordered with Keffa Zone in North, Debub Omo in North East, Sheka Zone in South West, with Gambella and South Sudan Republic in South direction (BMZARD, 2014). Agro-ecologically, BMZ, consists of 52 percent lowland (500-1500 masl), 43 percent intermediate highland (1500-2300 m.a.s.l) and 5 percent highland (>2300 masl). It has an altitude ranging from 500-2500 m.a.s.l. The mean annual temperature varies from $15.10 \mathrm{C}-27.50 \mathrm{C}$. The mean annual rainfall ranges from 400-2000 mm (BMZARD, 2014). Bench Maji Zone has 10 districts from which this study involved three districts; namely North-bench, Sheko and South-bench.

Sampling Techniques for Data Collection: A rapid field survey was made prior to the actual survey work to explore the available knowledge about the type, distribution and utility of chicken types. The data on distribution and numbers of indigenous chickens were taken from office of Agriculture and Rural Development (BMZARD) of each district in the zone before starting the field work. Then three districts and a total of nine peasant associations (PAs) were selected based on the information gathered through the rapid field survey to the main road and consultations with Woreda's Agricultural experts and extension agents. A total of 180 households (60 from each district) were sampled for interview from the selected PAs. For linear body measurements a total of 180 male and 480 female indigenous chickens, approximately six months age or older were selected and measurements taken.

Data Collection Procedure: The data were generated through observation, administering a structured questionnaire, employing linear body measurements, organizing group discussion and from secondary sources.

Measurement of Phenotypic Traits: A total of 660 indigenous chickens of both sexes: 220 chickens (60 male and 160 female) from North Bench, 220 chickens (60 male and 160 female) from Sheko and 220 chickens (60 male and 160 female) from South Bench were randomly selected. Quantitative traits (shank length, comb height, comb length, body length, neck length, back length, keel length, wattle length, wingspan, and body weight) and qualitative traits (plumage color, skin color, shank color, shank feather, comb type, earlobe color, head shape) were recorded following the recommended FAO descriptors for chicken genetic resources (FAO, 2012). Measuring tapes and a digital balance of $1 \mathrm{~g}$ precision were used to measure the respective quantitative traits and body weight of sampled chickens.

Data Management and Statistical Analysis: All data were coded and recorded in Microsoft excel sheet. Statistical analyses were made separately for male and female chicken on variables that varied on sex; otherwise the data were merged and analyzed together.
Descriptive Statistics: Statistical analysis system (SAS) version 9.2 (2008) was used to carry out descriptive statistics on qualitative and quantitative variables of the identified indigenous chicken populations.

Univariate Analysis: A general linear model procedure (PROC GLM) of the SAS was employed for quantitative variables to detect statistical differences among sampled indigenous chicken populations. For mature animals, sex and location of the experimental indigenous chickens were fitted as fixed independent variables. The effects of class variables and their interaction were expressed as Least Square Means (LSM) \pm SE. Mean comparisons were made using Turkey's studentized range test method at $P<0.05$.

\section{RESULTS AND DISCUSSION}

\section{Variation in Qualitative Traits}

Qualitative traits such as plumage color, comb type, shank color, ear lobe color, skin color, shank feather, head shape and hen spurs were evaluated in the three district. As presented in Table 1, about $58.33 \%$ of the male chicken populations in north-bench district were characterized by black plumage color followed by white and Gebsima (15.0\%) and also red (11.88\%). Majority of chicken population in sheko district were characterized by red plumage $(68.33 \%)$, Gebsima $(15.00 \%)$ and White $(8.33 \%)$. Similarly, most of south-bench chicken populations were characterized by red plumage $(70 \%)$, Gebsima $(16.67 \%)$ and white $(5 \%)$. Aberra and Tegene (2011) reported that geographical isolation as well as periods of natural and to some extent artificial selections could be the reason for large variations in plumage color.

Feather morphology of the studied chicken populations was normal in all the study districts (Table.2). This is similar with the findings of Bogale (2008) who reported normal feather morphology in all of the local chicken populations in Fogera woreda, Ethiopia. However, Niguse et al., (2010b) reported $52-66 \%$ and $34-48 \%$ for normal and silky feathers, respectively, from the five local chicken ecotypes in Ethiopia. This variation might be attributed to differences in breed type among the local chicken ecotypes in Ethiopia. The studied chicken populations had normal and naked neck feather distribution. The normal feather distribution was observed dominantly (95\%) in studied districts followed by naked-neck $(5.00 \%)$, crested $(12.27 \%)$, hen spurred (43.64 \%) and feathery shank (2.27\%). According to Aberra and Tegene (2011) 83.2\% of the chicken populations in southern region of Ethiopia had normal feather distribution followed by naked-neck $(7.9 \%)$, crested $(5.6 \%)$, feathery shank and feet $(2.0 \%)$.

Regarding skin color white, pink and yellow skin colors were observed. Among these the white skin was the most dominant in all the three indigenous chicken populations. The yellow or white skin is the results of the presence or absence of carotenoids pigments (Eriksson et al., 2008). Yellow skin color is the result of the expression of carotenoid pigments in the skins of birds (Smyth, 1990) and according to Eriksson et al. (2008), it is generally considered to be associated with the individual's adaptive fitness reflecting its nutritional status or health which, in turn, is indicative of its foraging efficiency and immune status. On the investigated chicken populations four comb types were observed in which single, doublex, strawberry and rose comb types were the most dominant ones, respectively. 
Table 1: Plumage color variation of chicken

\begin{tabular}{|c|c|c|c|c|c|c|c|c|c|}
\hline \multirow{3}{*}{$\begin{array}{l}\text { Plumage } \\
\text { color }\end{array}$} & \multicolumn{9}{|c|}{ Districts } \\
\hline & \multicolumn{3}{|c|}{ North-bench } & \multicolumn{3}{|c|}{ Sheko } & \multicolumn{3}{|c|}{ South-bench } \\
\hline & $\begin{array}{c}M \\
(60)\end{array}$ & $\begin{array}{c}F \\
(160)\end{array}$ & $\begin{array}{l}\text { Total } \\
(220)\end{array}$ & $\begin{array}{c}M \\
(60) \\
\end{array}$ & $\begin{array}{c}F \\
(160)\end{array}$ & $\begin{array}{l}\text { Total } \\
(220)\end{array}$ & $\begin{array}{c}M \\
(60)\end{array}$ & $\begin{array}{c}F \\
(160)\end{array}$ & $\begin{array}{l}\text { Total } \\
(220)\end{array}$ \\
\hline White & $9(15.00)$ & $11(6.88)$ & $20(9.09)$ & $5(8.33)$ & $8(5.00)$ & $13(5.91)$ & $3(5.00)$ & $12(7.50)$ & $15(6.82)$ \\
\hline Black & $35(58.33$ & $16(10.00)$ & $51(23.18)$ & $3(5.00)$ & $33(20.63)$ & $36(16.36)$ & $2(3.33)$ & $25(15.63)$ & $27(12.27)$ \\
\hline Red & $7(11.67)$ & $30(18.75)$ & $37(16.82)$ & 41(68.33) & $35(21.88)$ & $76(34.55)$ & $42(70.00)$ & $34(21.25)$ & $76(34.55)$ \\
\hline Gebsima & $9(15.00)$ & $20(12.50)$ & $29(13.18)$ & $9(15.00)$ & $16(10.00)$ & $25(11.36)$ & $10(16.67)$ & 19(11.88) & $29(13.18)$ \\
\hline Teterima & - & $32(20.00)$ & $32(14.55)$ & $1(1.67)$ & $20(12.50)$ & $21(9.55)$ & $2(3.33)$ & $41(25.63)$ & $43(19.55)$ \\
\hline Brown & - & - & - & - & - & - & $1(1.67)$ & $8(5.00)$ & $9(4.09)$ \\
\hline Kokima & & $51(31.88)$ & $51(23.18)$ & $1(1.67)$ & $48(30.00)$ & $49(22.27)$ & - & $17(10.63)$ & $17(7.72)$ \\
\hline Grey & - & - & - & - & - & - & - & $3(1.88)$ & $3(1.36)$ \\
\hline Zigrima & - & - & - & - & - & - & - & $1(0.63)$ & $1(0.45)$ \\
\hline$X 2=60.52$ & & & & & & & & & \\
\hline
\end{tabular}

$X^{2}=$ Pearson chi-square. ${ }^{*}$ Significant at $P<0$, numbers in brackets are out of 100 percentage.

Table 2: Morphological characteristics of indigenous chicken ecotypes

\begin{tabular}{|c|c|c|c|c|}
\hline \multirow{2}{*}{ Traits (Frequency, \%) } & \multicolumn{4}{|c|}{ District } \\
\hline & North-bench (N (\%)) & Sheko (N (\%)) & South-bench (N (\%)) & $x^{2}$ \\
\hline Feather morphology & & & & - \\
\hline Normal & $220(100)$ & $220(100)$ & $220(100)$ & \\
\hline Feather distribution & & & & $3.23^{\mathrm{ns}}$ \\
\hline Normal & 205(93.18) & $213(97.26)$ & $210(95.00)$ & \\
\hline Naked neck & $15(6.82)$ & $7(2.74)$ & $10(5.00)$ & \\
\hline Shank color & & & & $12.93^{\mathrm{ns}}$ \\
\hline white & $50(22.73)$ & $62(28.31)$ & $46(20.91)$ & \\
\hline Red & $1(0.45)$ & $2(0.91)$ & $1(0.45)$ & \\
\hline Yellow & $96(43.64)$ & $83(37.90)$ & 119(54.09) & \\
\hline Grey & $73(33.18)$ & $72(32.88)$ & $54(24.55)$ & \\
\hline Ear lobe color & & & & 73.02 * \\
\hline White & $36(16.36)$ & $41(18.72)$ & $60(27.27)$ & \\
\hline Red & $53(24.09)$ & $27(12.33)$ & $44(20.00)$ & \\
\hline Yellow & $56(25.45)$ & $15(6.85)$ & $51(23.18)$ & \\
\hline White and Red & $75(34.09)$ & $137(62.10)$ & $65(29.55)$ & \\
\hline Skin color & & & & $39.97^{*}$ \\
\hline Yellow & $8(3.64)$ & $6(2.28)$ & $18(8.18)$ & \\
\hline White & $182(82.27)$ & 197(89.95) & $145(65.45)$ & \\
\hline Pink & $30(14.09)$ & $17(7.76)$ & $57(26.37)$ & \\
\hline Comb type & & & & $9.75^{*}$ \\
\hline Single & $190(86.36)$ & $198(89.50)$ & $186(84.55)$ & \\
\hline Rose & $1(0.45)$ & $1(0.45)$ & $3(1.36)$ & \\
\hline Strawberry & $1(0.45)$ & $6(2.74)$ & $5(2.27)$ & \\
\hline Double & $28(12.73)$ & $15(6.85)$ & $26(11.82)$ & \\
\hline Head shape & & & & $1.79^{\mathrm{ns}}$ \\
\hline Plain & 193(87.73) & $195(88.58)$ & $186(84.55)$ & \\
\hline Crest & 27 (12.27) & $25(11.42)$ & $34(15.45)$ & \\
\hline Hen spur & & & & $3.85^{\mathrm{ns}}$ \\
\hline Present & $96(43.64)$ & $81(36.53)$ & 77 (35.00) & \\
\hline Absent & $124(56.36)$ & $139(63.47)$ & $143(65.00)$ & \\
\hline Shank feather & & & & $0.34^{\mathrm{ns}}$ \\
\hline Present & $5(2.27)$ & $6(3.20)$ & $7(3.18)$ & \\
\hline Absent & $215(97.73)$ & $214(96.80)$ & $213(96.82)$ & \\
\hline
\end{tabular}

Of the total sampled chicken populations $86.36 \%$ from north-bench $89.50 \%$ from sheko and $84.55 \%$ from southbench were single combed, whereas doublex comb accounts for $12.73 \%, 6.85 \%$ and $11.82 \%$ in the respective districts. These frequencies are in contrast with the value reported by Eskindir (2013) who found $33.49 \%$ and $48.65 \%$ of chicken in Horro and Jarso, single comb type. In the current study four earlobe colors were observed on the sampled chicken populations. The white 
Getachew Bekele et alo,

and red earlobe was the commonest color in north bench (34.09\%).

Sheko $(62.10 \%)$ and $(29.55 \%)$ dominant in southbench. The proportion of chickens with red earlobe was almost comparable among studied districts. In contrast, the white, yellow and red earlobe was observed with a very low proportion in all sampled chicken populations of the north-bench, Sheko and south-bench respectively. According to Nigussie et al., (2010b), the proportion of indigenous chickens showing white, red and yellow earlobe was $40 \%, 52 \%$ and $8 \%$, respectively, which are in line with the current study.

Four shank colors were also observed in all the study districts. The proportion of chickens having yellow shanks was dominant in north-bench $(43.64 \%)$, sheko $(37.90 \%)$ and (54.09) south-bench. And grey shank color was observed by $33.18 \%, 32.88 \%$, and $24.55 \%$ in northbench, sheko and south-bench respectively. The shanks and most of the feet are covered with scales of different colors. Yellow is due to dietary carotenoid pigments in the
Sci. Technol. Arts Res. J., Jan-March 2015, 4(1): 68-73

epidermis when melanic pigment is absent. Varying shades of black are the result of melanic pigment in the dermis and epidermis. When there is black pigment in dermis and yellow in epidermis, the shanks have greenish appearance. In the complete absence of both of these pigments, the shanks are white.

\section{Multiple Correspondence Analyses}

To describe the typical features of indigenous chickens genetic resource in all three district for morphological characteristics, multiple correspondence analysis was carried out on qualitative traits which were significantly $(P<0.05$ figure 1$)$ different between the sampled chicken population in the three districts. Figure.1 shows a bi-dimensional graph representing the associations among the categories of the analyzed qualitative traits. The interpretation is based on points found in approximately the same direction from the origin in approximately the same region of the space. From the figure, it can be shown that $15.45 \%$ of the total variations are explained by the two dimensions $(8.81 \%$ by the first and $6.64 \%$ by the second dimensions).

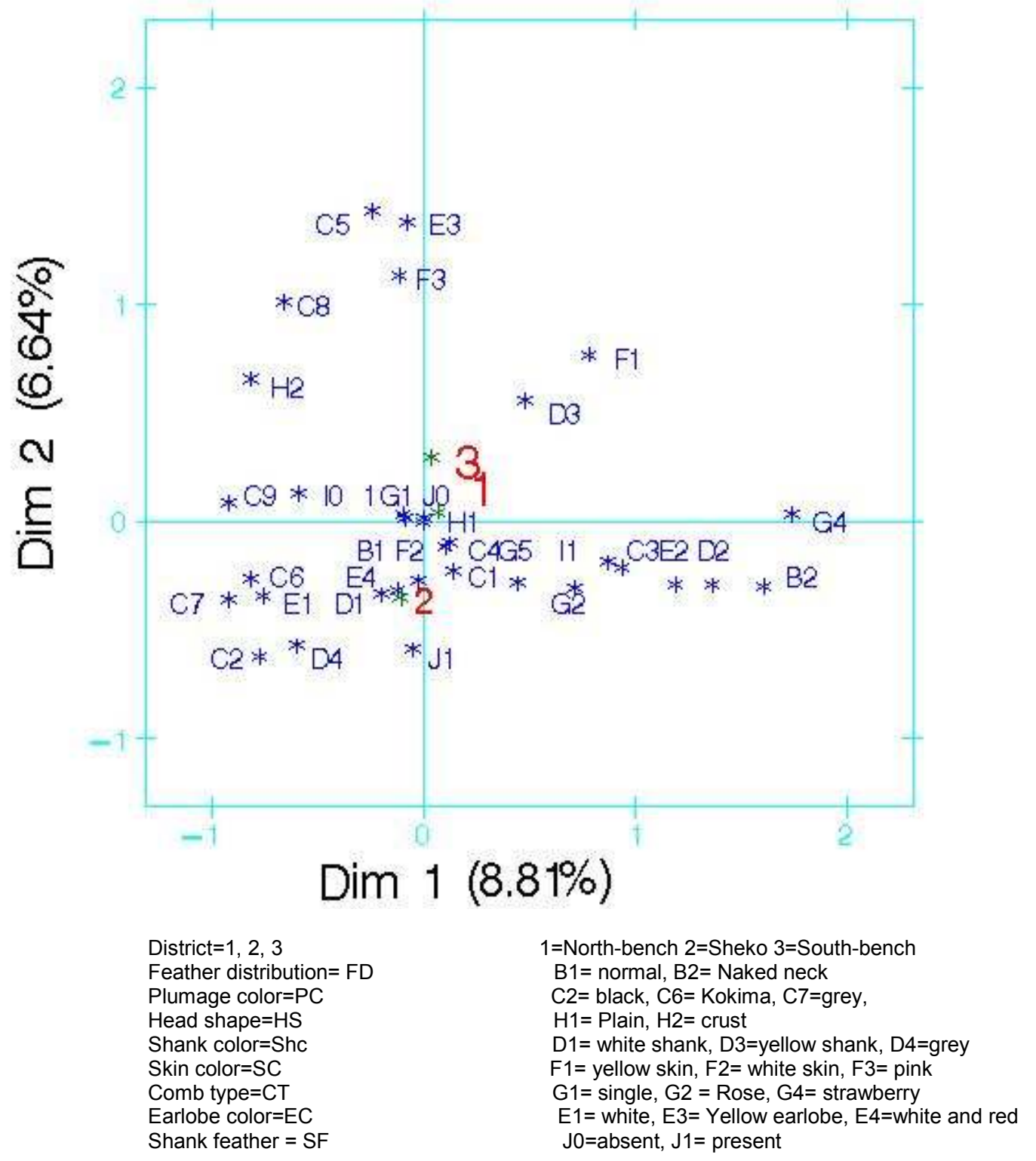

Figure 1: The bi-dimensional graph showing the correspondences among the categories of the different morphological characteristics 
Getachew Bekele et al.,

On the identified dimensions, the sampled indigenous chicken populations from sheko district were closely clustered together with white and red earlobe color, normal feather distribution, white skin color, Kokima and Brown plumage color, Grey shank color, White earlobe color, White shank color and yellow skin color. The sample chicken populations from north-bench were categorized under a plain head shape, yellow skin color, yellow shank color, strawberry comb type and absence of shank feather. While chicken populations in south-bench were closely clustered a yellow earlobe color, pink skin color, plain head shape, yellow skin color and yellow shank color.

\section{Variation in Quantitative Traits \\ Body Measurements and Weights of Indigenous Chicken Populations}

The body weight and body measurements of male and female chicken populations in the three districts are
Sci. Technol. Arts Res. J., Jan-March 2015, 4(1): 68-73

presented in Table 3 . The average body weight of adult males and females were significantly $(P<0.05)$ different between the study districts. Males and females in south bench were significantly heavier compared to their counterparts in sheko and north-bench districts. The body weight for adult males were $1.61 \mathrm{~kg}, 1.36 \mathrm{~kg}$ and $1.29 \mathrm{~kg}$ in south-bench, sheko and north-bench district, respectively, which is lower than $2049 \mathrm{~g}$ for males in northwest Ethiopia (Halima, 2007) and in agreement with $1690 \mathrm{~g}$ for Horro and $1420 \mathrm{~g}$ for Jarso male ecotypes (Eskinder, 2013).While the values for adult females were $1.24 \mathrm{~kg}, 1.18 \mathrm{~kg}$ and $1.13 \mathrm{~kg}$ in south-bench, sheko and north-bench districts, respectively which is in line with the values reported for the Central Highlands of Ethiopia (1035 g) by Alemu and Tadelle (1997) and the value reported for Horro $(1289 \mathrm{~g})$ and Jarso (1116 g) by Eskinder (2013) but higher than the value reported for north-west Ethiopia (847.77 g) by Halima (2007).

Table 3: Morphometric variation of indigenous chicken

\begin{tabular}{|c|c|c|c|c|c|}
\hline \multirow{2}{*}{$\begin{array}{c}\text { Parameter } \\
\text { (mean } \pm \text { SE) }\end{array}$} & \multicolumn{5}{|c|}{ District } \\
\hline & Sex & North-bench & Sheko & South-bench & \\
\hline \multirow{2}{*}{ Comb height(cm) } & $M$ & $1.99 \pm 0.05^{b}$ & $2.20 \pm 0.05^{\mathrm{a}}$ & $2.27 \pm 0.05^{\mathrm{a}}$ & * \\
\hline & $\mathrm{F}$ & $0.97 \pm 0.03$ & $0.99 \pm 0.03$ & $0.94 \pm 0.03$ & ns \\
\hline \multirow{2}{*}{ Comb length(cm) } & $M$ & $4.72 \pm 0.08^{b}$ & $5.33 \pm 0.08^{\mathrm{a}}$ & $5.36 \pm 0.08^{a}$ & $*$ \\
\hline & $\mathrm{F}$ & $2.42 \pm 0.05$ & $2.53 \pm 0.05$ & $2.46 \pm 0.05$ & ns \\
\hline \multirow{2}{*}{ Wattle length $(\mathrm{cm})$} & $M$ & $2.98 \pm 0.05^{c}$ & $3.46 \pm 0.05^{b}$ & $3.69 \pm 0.05^{a}$ & $*$ \\
\hline & $\mathrm{F}$ & $1.04 \pm 0.03$ & $0.98 \pm 0.03$ & $0.99 \pm 0.03$ & ns \\
\hline \multirow{2}{*}{ Neck length(cm) } & $M$ & $17.55 \pm 0.15^{b}$ & $18.93 \pm 0.15^{\mathrm{a}}$ & $17.45 \pm 0.15^{\mathrm{bc}}$ & $*$ \\
\hline & $\mathrm{F}$ & $15.76 \pm 0.09 \mathrm{e}$ & $17.12 \pm 0.09 c$ & $16.20 \pm 0.09 d$ & * \\
\hline \multirow{2}{*}{ Back length $(\mathrm{cm})$} & $\mathrm{M}$ & $21.07 \pm 0.08 b$ & $21.38 \pm 0.13 a$ & $21.02 \pm 0.13 a b c$ & * \\
\hline & $\mathrm{F}$ & $20.73 \pm 0.13 c$ & $20.06 \pm 0.08 d$ & $19.01 \pm 0.08 \mathrm{e}$ & * \\
\hline \multirow{2}{*}{ Body length(cm) } & $M$ & $38.27 \pm 0.21^{b}$ & $40.38 \pm 0.21^{\mathrm{a}}$ & $38.47 \pm 0.21^{\mathrm{b}}$ & * \\
\hline & $\mathrm{F}$ & $36.78 \pm 0.13^{d}$ & $37.21 \pm 0.13^{c}$ & $35.18 \pm 0.13^{\mathrm{e}}$ & * \\
\hline \multirow{2}{*}{ Wing span $(\mathrm{cm})$} & $M$ & $63.30 \pm 0.29^{c}$ & $65.52 \pm 0.29^{b}$ & $67.48 \pm 0.29^{a}$ & * \\
\hline & $\mathrm{F}$ & $55.71 \pm 0.18^{\mathrm{e}}$ & $58.14 \pm 0.18^{d}$ & $55.00 \pm 0.18^{f}$ & * \\
\hline \multirow{2}{*}{ Shank length $(\mathrm{cm})$} & $M$ & $9.98 \pm 0.08^{b}$ & $10.29 \pm 0.08^{\mathrm{a}}$ & $10.45 \pm 0.08^{\mathrm{a}}$ & * \\
\hline & $\mathrm{F}$ & $8.48 \pm 0.08^{c}$ & $8.60 \pm 0.08^{c}$ & $7.79 \pm 0.05^{\mathrm{d}}$ & * \\
\hline \multirow{2}{*}{ Keel length $(\mathrm{cm})$} & $M$ & $11.29 \pm 0.10^{c}$ & $11.67 \pm 0.10^{b}$ & $12.02 \pm 0.10^{a}$ & * \\
\hline & $\mathrm{F}$ & $10.54 \pm 0.06^{\mathrm{d}}$ & $10.33 \pm 0.06^{\mathrm{e}}$ & $10.12 \pm 0.06^{f}$ & * \\
\hline \multirow{2}{*}{ Body weight(kg) } & $M$ & $1.29 \pm 0.02^{c}$ & $1.36 \pm 0.02^{b}$ & $1.61 \pm 0.02^{\mathrm{a}}$ & * \\
\hline & $\mathrm{F}$ & $1.13 \pm 0.01^{f}$ & $1.18 \pm 0.01^{\mathrm{e}}$ & $1.24 \pm 0.01^{d}$ & * \\
\hline
\end{tabular}

$a, b, c, d, e, f$ means in a row with different superscript letters denote significant differences between populations or sampling districts $(p<0.05)$ and asterisks $\left({ }^{*}\right)$ within a column indicate significant differences between males and females for each parameter at the $5 \%$ level of probability and $(n s)=$ non-significance.

The average shank length of adult males in northbench and adult females in south- bench were significantly $(P<0.05)$ different from the other districts. The average shank length of males found in this study is comparable with the reported average value of $9.1 \mathrm{~cm}$ for the five chicken ecotypes in Ethiopia (Nigussie et al., $2010 \mathrm{~b}$ ) but shorter than the reported $11.3 \mathrm{~cm}$ in Horro and $10 \mathrm{~cm}$ in Jarso ecotypes, by Eskinder (2013). Similarly, the female shank length is in line with the range of shank length $9.2 \mathrm{~cm}$ in Horro and $8.5 \mathrm{~cm}$ in Jarso ecotypes (Eskinder, 2013). But longer than $(6.6-7.8 \mathrm{~cm})$ in five ecotypes of Ethiopia (Nigussie et al., 2010b).

The comb length, comb height and wattle length also varied significantly among the districts. Significantly long legs, large combs and wattles were observed in southbench male chicken populations, which are important morphological traits that allow better heat dissipation in the tropical hot environment. The comb and wattles have a large role in sensible heat losses. This specialized structure makes up about $40 \%$ of the major heat losses, through radiation and convection of heat produced from body surfaces at the environmental temperature above 26.7 0c (Nesheim et al., 1979).

\section{CONCLUSION}

Poultry farming is widely practiced in Africa almost every farmstead keeps some poultry mainly for consumption and cash sales. Ethiopia, with its wide variations in agro climatic conditions, possesses one of the largest and the most diverse plant and animal genetic resources in the world. The present study was therefore conducted in Bench Maji zone of south-western regional state (SNNPR) to describe the existing chicken production system, identify, characterize and describe the phenotypic variation of indigenous chicken populations. Three 


\section{Getachew Bekele et alo,}

districts and nine peasant associations (three from each district) were purposively selected based on the information gathered through the rapid field survey and consultations with woreda agricultural experts, extension agents, and some farmers. A total of 180 households were randomly selected to participate in the survey, which were conducted using a structured questionnaire on chickens husbandry and other related issues and a total of 660 matured chickens (220 from each district) were randomly selected for the qualitative trait description and quantitative trait measurements. The data were subjected to descriptive statistics, frequency procedure and univariate analysis of SAS version 9.2 (2008). The average shank length of adult males and females in northbench were significantly $(P<0.05)$ different from the other districts. The comb length, comb height and wattle length also varied significantly among the districts. Significantly long legs, large combs and wattles were observed in south-bench male and female chicken populations, which are important morphological traits that allow better heat dissipation in the tropical hot environment.

\section{Conflict of Interest}

Conflict of interest none declared.

\section{REFERENCE}

Aberra Melesse and Tegene Negese. (2011). Phenotypic and morphological characterization of Indigenous chicken population in Southern region of Ethiopia. Animal Genetic Resources Information Journal 49:19-31.

Alemu Yami and Tadelle Dessie. (1997). The status of Poultry research and development in Ethiopia. Proceeding of the 5th National Conference of Ethiopian Society of Animal production (ESAP) 15-17 may, 1997, Addis Ababa, Ethiopia.

Bogale Kibret. (2008). In situ characterization of local chicken ecotype for functional traits and production system in Fogera woreda, Amhara regional state. Msc Thesis. Submitted to the Department of Animal Science. Haramaya University. Ethiopia. Pp.123.

CSA (Central Statistical Agency). (2012). Agricultural Sample Survey, report on livestock and livestock characteristics (Private Peasant Holdings). Federal democratic republic of Ethiopia,

CSA (Central Statistical Agency) (2012). Agricultural Sample Survey, report on livestock and Draft guidelines on phenotypic characterization of animal genetic resources. FAO, Rome, Italy.
Sci. Technol. Arts Res. J., Jan-March 2015, 4(1): 68-73

Dwinger, R.H., Bell, J.G. and Permin, A. (2003). A program to improve family poultry production in Africa. B.P. 6268, Rabat-Institutes, Morocco.

Eriksson J.G., Larson U. and Gunnarsson B. (2008). Identification of the yellow skin gene reveals a hybrid origin of the domestic chicken. PloS Genet 4(2): e1000010. doi:10.1371/journal.pgen.1000010.

Eskinder Aklilu (2013). On-farm phenotypic characterization of indigenous chicken and chicken production systems in horro and Jarso districts, Oromia regional state. Msc Thesis. Submitted to the Department of Animal and Range Science. Haramaya University. Ethiopia. Pp.94.

Food and Agriculture Organization of the United Nations (FAO), (2012). Chicken descriptors. Free State, Bloemfontein, South Africa. Pp186

Gueye, E.F. (1998). Village egg and fowl meat production in Africa. World's Poultry Science Journal 54(1): 73-86.

Halima Hassen (2007). Phenotypic and genetic characterization of indigenous chicken populations in North-West Ethiopia. PhD Thesis. Submitted to the faculty of natural and agricultural sciences department of animal, wildlife and grassland Sciences. University of the livestock characteristics (Private Peasant Holdings). Federal democratic republic of Ethiopia,

Nesheim, C.M., Austic, E.R.and Card, E.L. (1979). Poultry production. Lea and Febiger. Philadelphia. $12^{\text {th }}$ edition. pp 58-92.

Nigussie Dana., Liesbeth, H., van der Waaij., Tadelle Dessie., Johan A.M. and van Arendonk. (2010b). Morphological features of indigenous chicken populations of Ethiopia. Animal Genetic Resources, 2010, 46, 11-23. (C) Food and Agriculture Organization of the United Nations, 2010 doi: 10.1017/ S2078633610000652.

SAS (Statistical Analysis System) (2008). SAS Institute Inc., Cary, NC, USA.V.9.2

Tadelle Dessie (2003). Phenotypic and genetic characterization of chicken ecotypes in Ethiopia. PhD Thesis. Humboldt University, Germany. Pp216.

Tadelle, D., Million, T., Alemu Yami and Peters. K.J. (2003). Village chicken production systems in Ethiopia: Use patterns and performance evaluation and chicken products and socioeconomic functions of chicken. Livestock Research for Rural Development 15 (1). Retrieved Dec 31, 2014, from http://www.Irrd.org/ Irrd15/1/tadeb151.htm 